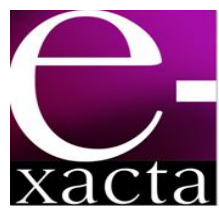

ISSN: 1984-3151

\title{
AVALIAÇÃO DE REVESTIMENTO REFRATÁRIO NO PROCESSO SIDERÚRGICO
}

\author{
EVALUATION WITH REFRACTORY COATING ON STEEL PROCESS
}

\author{
Luiza Santos Cotta ${ }^{1}$; Christianne Garcia Rodrigues ${ }^{2}$
}

1 Bacharel em Engenharia Química. Centro Universitário de Belo Horizonte, 2013. Belo Horizonte, MG. lucotta@hotmail.com.

2 Mestre em Engenharia Metalúrgica. UFMG, 1998. Professora do Centro Universitário de Belo Horizonte UNIBH. Belo Horizonte, MG. cg.rodrigues@hotmail.com.

Recebido em: 03/01/2014 - Aprovado em: 20/04/2014 - Disponibilizado em: 31/05/2014

RESUMO: É necessário que os equipamentos utilizados no processo siderúrgico sejam revestidos com materiais refratários, para não prejudicar seu desempenho nem danificar sua carcaça devido às elevadas temperaturas de atuação. Os materiais refratários possuem como funções básicas contenção de metal líquido e isolamento térmico. Sua durabilidade depende do conjunto de fatores e das solicitações às quais está sujeito. Tais solicitações variam de acordo com a região de cada equipamento, definindo o padrão de desgaste do revestimento. O presente trabalho teve como objetivo realizar um estudo de caso para avaliar as causas de uma baixa campanha de um tijolo refratário usado no distribuidor de uma usina siderúrgica, através da análise PostMortem. Foram coletados dois tijolos da região afetada, e ainda a escória que interagiu com tais tijolos foi analisada. Foram realizados testes de análise química por fluorescência de raios- $\chi$, difração de raios- $x$, perda ao fogo, microscopia, densidade e porosidade. De acordo com a análise Post-Mortem, comprovou-se que os tijolos do distribuidor sofreram infiltrações de aço e escória. Ao analisar esta última, percebeu-se tratar-se de uma escória ácida, com MgO de saturação superior ao teor livre. Além disso, sua temperatura de líquidus indicou uma escória fluida, ainda mais agressiva ao refratário. Por esse motivo, a massa de cobertura do distribuidor, utilizada como revestimento de trabalho, não suportou as condições de operação, e o distribuidor passou a operar sob o revestimento permanente, que não foi desenvolvido para trabalhar diretamente com o metal líquido.

PALAVRAS-CHAVE: Processo siderúrgico. Revestimento refratário. Distribuidor. Post-Mortem. Escória.

ABSTRACT: Is necessary that the equipment used in the steel process are coated with refractory materials, so it will not harm its performance, and damage their casing due to the high temperatures of operation. The refractory materials have basics functions like the containment of liquid metal and thermal insulation. The durability of the refractory coating depends on a set of factors and applications in which it is subject. Such applications vary according to the region of each equipment, by setting the wear pattern of the coating. This study aimed to conduct a case study to assess the causes of a low campaign a firebrick used in a steel mill tundish, through the analysis Post-Mortem. It was collected two bricks from the affected region. And the slag which interacted with this bricks was also analyzed. Several tests were conducted, like, a chemical analysis by fluorescence $X$-ray, X-ray diffraction, ignition loss, microscopy, density and porosity. According to Post-Mortem analysis it was proved that the tundish's bricks underwent infiltrations of steel and slag. By analyzing the slag that was in contact with the bricks, it was noticed that it was an acid slag, with $\mathrm{MgO}$ saturation higher than the content free. Moreover, the melting temperature indicated a fluid slag, even more aggressive in refractory. For this reason, the mass coverage of the tundish, used to coat work, did not support the operating conditions and the tundish has operated under the permanent coating, which was not designed to work directly with the liquid metal. KEYWORDS: Steel process. Refractory coating. Tundish. Post-Mortem. Slag. 


\section{INTRODUÇÃo}

O processo metalúrgico pode ser definido como o conjunto de tratamentos físicos e químicos a que são submetidos os minerais para a extração de metais. Registros constatam seu surgimento há mais de seis mil anos, quando o material dominante ainda era o bronze (MOURÃO; GENTILE, 2011).

Os mesmos autores afirmam que a descoberta de minérios de ferro de alta qualidade fez com que o ferro passasse a ser a principal matéria-prima do processo, dando início à expansão da siderurgia. $O$ processo siderúrgico é baseado na utilização de uma fonte de carbono para reagir com um sopro de ar, visando ao beneficiamento do minério de ferro, com auxílio de trabalho térmico e mecânico, transformando-o em aço.

Após a Revolução Industrial, o papel da indústria do aço no desenvolvimento mundial tem sido cada vez mais importante. O final século XIX foi marcado por um grande aumento na produção mundial de aço, com desenvolvimento de processos revolucionários de conversão de gusa. Na segunda metade do século $X X$, a siderurgia no Brasil teve um grande desenvolvimento com a inauguração da usina de Monlevade (MOURÃO et al, 2002).

O processo de transformação de ferro em aço foi evoluindo junto à civilização, impulsionado pelas indústrias de base, sendo otimizado com inovações tecnológicas e com o desenvolvimento de novas práticas. Para se ter uma ideia, um alto-forno moderno pode produzir, nos dias de hoje, o equivalente a 13.000 toneladas de ferro gusa de qualidade estável por dia, e ainda possui alta produtividade, vida útil média de 15 anos e baixo consumo de combustível (MOURÃO; GENTILE, 2011).

Para se realizar as operações de uma indústria siderúrgica, é necessário que os equipamentos sejam revestidos com materiais refratários, visto que as temperaturas de atuação dos equipamentos são muito elevadas, podendo prejudicar seu desempenho e danificar sua carcaça, caso não sejam devidamente revestidos. Tais revestimentos são usados nas usinas siderúrgicas visando-se à contenção do metal líquido e isolamento térmico, contribuindo assim para a melhoria da limpidez do aço, respeitando a segurança operacional.

Os refratários têm uma vasta aplicabilidade industrial, podendo ser utilizados em indústrias siderúrgicas, de cimento, cerâmica, fundição, vidro, alumínio, química e petroquímica.

A escolha do refratário ideal para cada aplicação depende do mecanismo físico-químico que é predominante no processo (IBAR, 2012). As propriedades e especificações técnicas requeridas ao refratário decorrem basicamente da posição de sua aplicação ao longo do equipamento, do tipo de interação com as matérias-primas e escória, e dos produtos das reações de transformações (DUARTE, 2012). O desempenho dos produtos refratários dependerá do resultado das suas propriedades nas condições de sua utilização (MATOS, 2001).

Visto a grande importância do processo siderúrgico no cenário mundial e a consequente necessidade da aplicação de um revestimento refratário de qualidade nos equipamentos, o presente trabalho tem como objetivo geral a realização de um estudo de caso para avaliar as causas de uma baixa campanha de um tijolo refratário usado no distribuidor de uma usina siderúrgica e, ainda, como objetivos específicos conhecer o processo metalúrgico de fabricação do aço, identificar as propriedades do tijolo refratário após sua utilização e comparar essas propriedades com a de um tijolo novo (sem utilização). A pesquisa se justifica pelo fato de tanto a indústria siderúrgica como a de refratários necessitarem da atuação de um engenheiro químico; seja para controlar o processo, detectar possíveis falhas ou ainda desenvolver novos produtos. 
O presente trabalho estudará as causas de uma baixa campanha de um tijolo refratário usado em um distribuidor de uma usina siderúrgica, por meio da análise Post-Mortem. Para realizar esse estudo, o levantamento de dados deve ser o mais completo concebível, se possível com registros fotográficos da região sendo considerada. Além do refratário usado, os materiais em contato com esse devem ser analisados, assim como as informações colhidas no usuário. Todos esses dados coletados são de extrema importância para se chegar a uma conclusão da causa do desgaste prematuro do material refratário.

\section{Processo SIDERÚRGICO}

As usinas siderúrgicas atuais podem ser divididas em dois grandes grupos: usinas integradas e semiintegradas. Usina integrada é aquela em que o aço é obtido a partir do ferro primário, isto é, a matéria-prima é o minério de ferro, que é transformado em ferro na própria usina nos alto-fornos, cujo produto chamado ferro gusa é transformado em aço através da operação de conversão. Uma usina semi-integrada é aquela na qual o aço é obtido a partir de ferro secundário e a matéria-prima é sucata de aço, não havendo necessidade da etapa de redução do minério de ferro. A sucata é transformada novamente em aço comercial, por meio do emprego de fornos elétricos de fusão, que são recicladores de aço (MOURÃO; GENTILE, 2011).

O ferro é um metal de propriedades que apresentam grandes variações, em função de sua composição química e tratamento termomecânico. Em particular, o carbono, sempre presente no ferro gusa devido ao uso de carvão, afeta muitas das propriedades importantes no processo de obtenção e nas características do produto final. Observa-se que o ferro puro é um material de baixa dureza e resistência, e o aumento do teor de carbono melhora estas propriedades. O ferro contendo acima de $0,35 \%$ de carbono, quando aquecido e depois resfriado bruscamente, adquire propriedades mecânicas excepcionais. À descoberta deste fenômeno, e do material assim produzido, que os antigos chamaram de aço, foi decisiva na difusão do ferro como o principal metal para a fabricação de ferramentas e armas (MOURÃO; GENTILE, 2011). O aço é uma liga metálica que contém geralmente de $0,002 \%$ a $2,0 \%$ do peso em carbono, além de outros elementos de liga nas mais variadas quantidades (MALYNOWSKYI, 2011). Para se reduzir um óxido de ferro por carbono, injeta-se sopro de ar em uma mistura de minério e carvão, contida em local isolado da atmosfera (MOURÃO; GENTILE, 2011).

O processo de alto-forno domina o cenário mundial de produção de aço (QUITES, 2011). Em uma moderna usina siderúrgica integrada, o processo que vai das matérias-primas ao produto final é constituído pelas seguintes etapas principais: extração do ferro de seu minério nos alto-fornos; a conversão do ferro gusa em aço; lingotamento do aço líquido de forma a se obter blocos, placas ou tarugos; seguido da laminação para a obtenção do produto final (MOURÃO; GENTILE, 2011).

As indústrias integradas procuram aperfeiçoar as misturas de minérios de ferro, como também as dos carvões minerais, objetivando conjugar menor custo com a melhor qualidade possível. Visando a essa otimização, realizam-se os processos de sinterização e coqueificação. A sinterização é o processo de aglomeração dos minérios de ferro, que, ao serem aquecidos junto aos finos de coque ou carvão, por uma frente de combustão, ocasionam uma ligação incipiente que produzirá 0 colamento entre as partículas de minério de ferro, resultando o sínter. A coqueificação nada mais é do que a mistura de carvões que resultam no "coque" (MOURÃO et al, 2002).

Os mesmos autores mostram que o minério de ferro é reduzido a ferro metálico nos alto-fornos, que são 
reatores cilíndricos verticais que trabalham a contracorrente. A carga a ser reduzida carbotermicamente (minério de ferro e coque) entra pelo seu topo e os gases redutores sobem da base para o topo do forno, em regime permanente. No altoforno é produzido o ferro gusa (sistema líquido que contém essencialmente ferro e carbono em solução a uma temperatura perto de $1500^{\circ} \mathrm{C}$ ), escória (sistema oxidado pelo líquido que contém os minerais de ganga do minério de ferro) e o gás de alto-forno (GAF, que sai pelo topo do alto-forno). São necessários alguns equipamentos auxiliares para que ocorra a redução da carga, tais como regeneradores, turbo soprador e sistema de limpeza de gases.

O ferro gusa, antes de ir para a aciaria sofre prétratamentos específicos, como de dessiliciação, desfosfatação e dessulfuração para minimizar a presença de silício $(\mathrm{Si})$, fósforo $(\mathrm{P})$ e enxofre $(\mathrm{S})$, e com isso facilita o processo de produção do aço com maior nível de qualidade. A escória sofre um processo de atomização com água, obtendo-se como produto escória particulada, o que auxilia sua venda para a indústria cimenteira. O GAF, após livrar-se do material particulado, é injetado nos regeneradores, como combustível, para aquecer o ar que é injetado no altoforno (MOURÃO et al, 2002).

Os mesmos autores também evidenciam que a aciaria é o setor da usina siderúrgica onde é refinado o ferro gusa, obtendo-se o aço. O processo consagrado, atualmente, é a conversão do ferro gusa no processo LD, no qual ele é oxidado, controladamente, por um fluxo de oxigênio lançado diretamente na superfície do banho através de uma lança.

Após o processamento, o aço líquido é transferido para um recipiente denominado panela, que é o reator metalúrgico para o processo de refino secundário, também chamado de Metalurgia de Panela. Esse refino nada mais é do que a eliminação de impurezas, denominadas inclusões, tais como: óxidos, sulfetos e nitretos, que na maior parte são prejudiciais para as propriedades mecânicas e/ou características desejadas no aço, causando diminuição da plasticidade e tenacidade, além de defeitos superficiais (BOLOTA, 2011).

A panela transporta 0 aço até 0 lingotamento, que consiste na última etapa da aciaria onde se trabalha com o metal ainda no estado líquido. Isso porque esse estágio tem como missão solidificar o aço, em uma forma desejável para ser utilizado nas etapas seguintes da cadeia produtiva (FACO, 2011).

Uma grande conquista do setor de aciaria foi o lingotamento contínuo que, além de minimizar problemas de superfície dos lingotes, já apresenta uma geometria de placa, pronta para a laminação (MOURÃO; GENTILE, 2011).

O processo siderúrgico também pode ser realizado em uma usina semi-integrada. Nesse caso, inicia-se com o processo de redução direta, cuja redução do minério de ferro a ferro metálico é efetuada sem que ocorra, em nenhuma fase do processo, a fusão da carga do reator. Assim, o produto metálico é obtido na fase sólida, e é chamado de ferro-esponja. Em geral, é usado posteriormente em fornos elétricos, onde é fundido para a obtenção do aço (MOURÃO, 2011).

Originariamente, o forno elétrico a arco (FEA) era simplesmente uma unidade de fusão para reciclar sucata de aço. Hoje, devido a numerosas modificações, ele está se tornando um reator elétrico e químico combinado. Sua utilização ainda apresenta a vantagem de uma maior quantidade de sucata poder ser reciclada (LEANDRO, 2011).

O aço é então encaminhado para o refino secundário e posteriormente para o lingotamento, que são realizados da mesma maneira que nas usinas integradas. A Figura 1 explicita todo esse processo detalhado de ambas as usinas. 


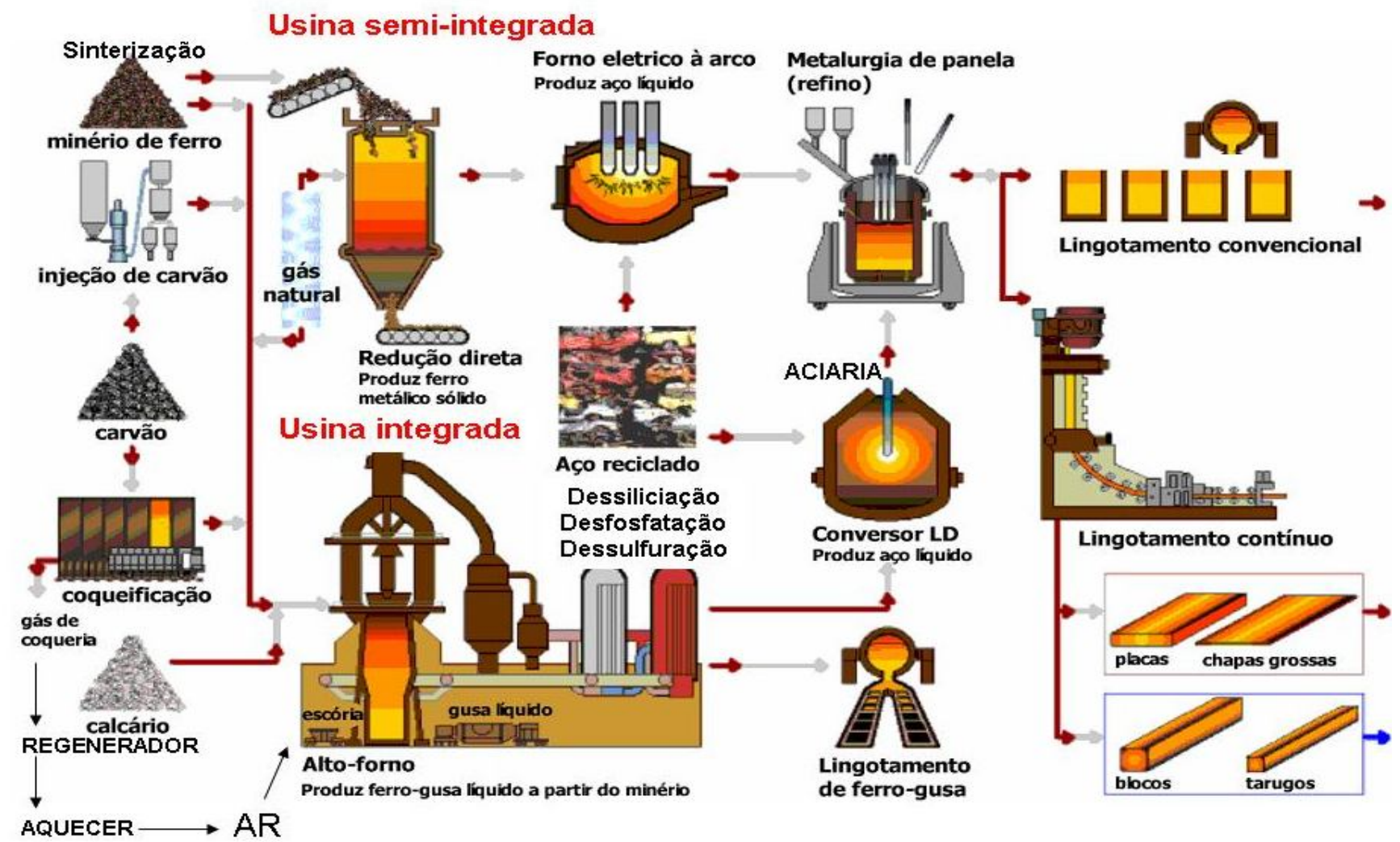

Figura 1 - Redução do minério de Ferro Fonte - MOREIRA modificada, s/d, p.4.

\subsection{LINGOTAMENTO CONTÍNUO}

No lingotamento contínuo, o vazamento do aço líquido ocorre verticalmente a partir da panela de operação do refino secundário, que é depositada em uma torre de panela. A vazão do aço através da panela é controlada por uma válvula gaveta, passando para o distribuidor com auxílio da válvula longa. No distribuidor, normalmente é utilizado um tampão para controlar o fluxo e encerramento do lingotamento do aço, que é posteriormente conduzido pela válvula submersa para dentro de um molde de cobre refrigerado. A solidificação se inicia no molde de cobre e continua durante a descida da peça (placa, bloco ou tarugo) pelos rolos de extração, conforme mostrado na Figura 2. As peças são então cortadas e enviadas à laminação (FACO, 2011).

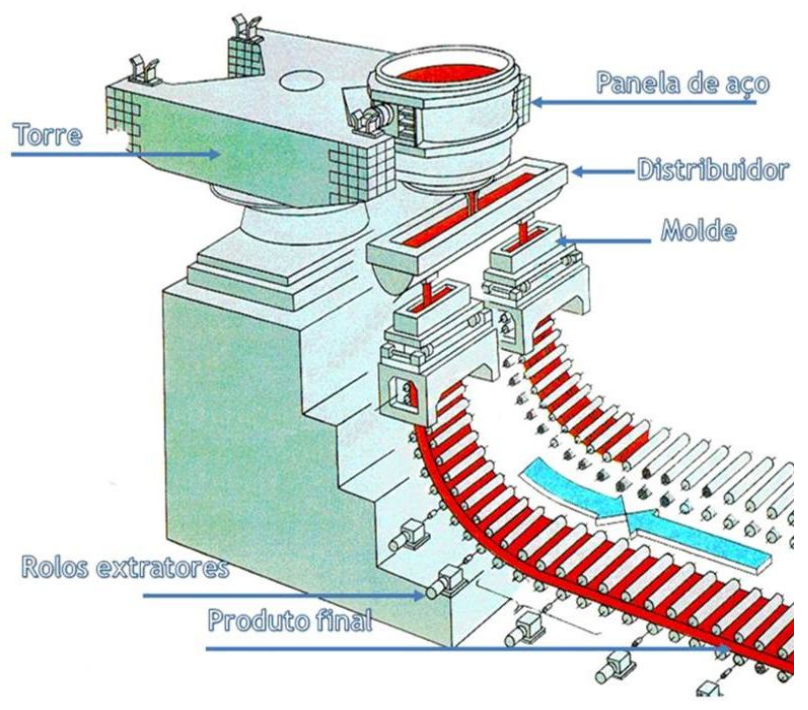

Figura 2- Lingotamento contínuo do aço Fonte: GALLO modificada, 2000. 


\section{REVESTIMENTO REFRATÁRIO}

O processo siderúrgico envolve temperaturas muito altas, e uma pré-condição para a obtenção do aço foi o desenvolvimento da cerâmica refratária (ARAÚJO, 1997). Os refratários cerâmicos constituem a solução mais apropriada aos problemas de altas temperaturas, e ainda resistem a solicitações químicas e mecânicas (MENEZES, 1989). O material refratário é aplicado entre a superfície metálica (carcaça do equipamento) e o meio corrosivo (metal líquido e escória) (DUARTE, 2003).

Materiais refratários são todos aqueles naturais ou manufaturados, não metálicos, capazes de resistir a ambientes hostis sob solicitações diversas, tais como altas temperaturas, altas cargas mecânicas, oscilações de temperaturas, abrasão, erosão, corrosão, impacto e outros. Trata-se de materiais multicomponentes, polifásicos, policristalinos, estáveis volumetricamente (DUARTE, 2012).

Em termos tecnológicos, os materiais refratários são classificados como materiais cerâmicos tradicionais. Porém, avanços tecnológicos ocorridos nas últimas décadas em vários campos da ciência e tecnologia, decorrentes de engenharia de aplicação, pesquisa e desenvolvimento, têm transformado os materiais refratários em produtos altamente especializados, inovadores e de elevado grau de sofisticação. As inovações desenvolvidas vão desde a otimização das microestruturas cerâmicas até a utilização de novas matérias-primas sintéticas; e, ainda, programas computacionais e equipamentos robotizados. A consequência direta dessa evolução tecnológica é observada pela diminuição do consumo específico dos refratários, em razão da produção do aço $(\mathrm{kg} /$ ton de aço) (SILVA, 2011).

O mesmo autor destaca que uma das características mais importantes dos materiais refratários é a capacidade de serem aplicados em condições extremas de temperatura $\left(>1580^{\circ} \mathrm{C}\right)$ e em ambientes corrosivos sujeitos a interações complexas com metais e escórias líquidas, mantendo suas propriedades estruturais e físico-químicas, além de minimizarem as perdas térmicas nos sistemas onde são utilizados. O conjunto destas características necessárias aos materiais refratários limita a ocorrência de uns poucos compostos químicos naturais ou sintéticos que satisfazem estas exigências, usualmente, e englobam óxidos ou suas misturas.

A compreensão da matéria-prima refratária é uma parte essencial dessa tecnologia. Isso porque as propriedades químicas e físicas específicas de uma matéria-prima controlam as propriedades finais do produto refratário. Seis óxidos formam a base dos produtos refratários: alumina $\left(\mathrm{Al}_{2} \mathrm{O}_{3}\right)$, magnésia $(\mathrm{MgO})$, sílica $\left(\mathrm{SiO}_{2}\right)$, zircônia $\left(\mathrm{ZrO}_{2}\right)$, cal $(\mathrm{CaO})$ e óxido crômico $\left(\mathrm{Cr}_{2} \mathrm{O}_{3}\right)$ (HANCOCK, 1988).

A produção de um material refratário envolve, inicialmente, a preparação das matérias-primas que serão utilizadas, através de britagem, moagem e classificação. Após esta etapa, podem ser estocadas, para uma posterior pesagem e dosagem nas quantidades especificadas para cada produto. Em sequência as matérias-primas são misturadas, em um programa específico para o refratário desejado. A etapa seguinte dependerá da classe de refratário a ser produzida: aqueles que necessitam de conformação (moldados) são então prensados, curados ou queimados, para serem embalados; já os outros (monolíticos) são apenas misturados e embalados. A Figura 3 apresenta o fluxograma detalhado do processo produtivo. 


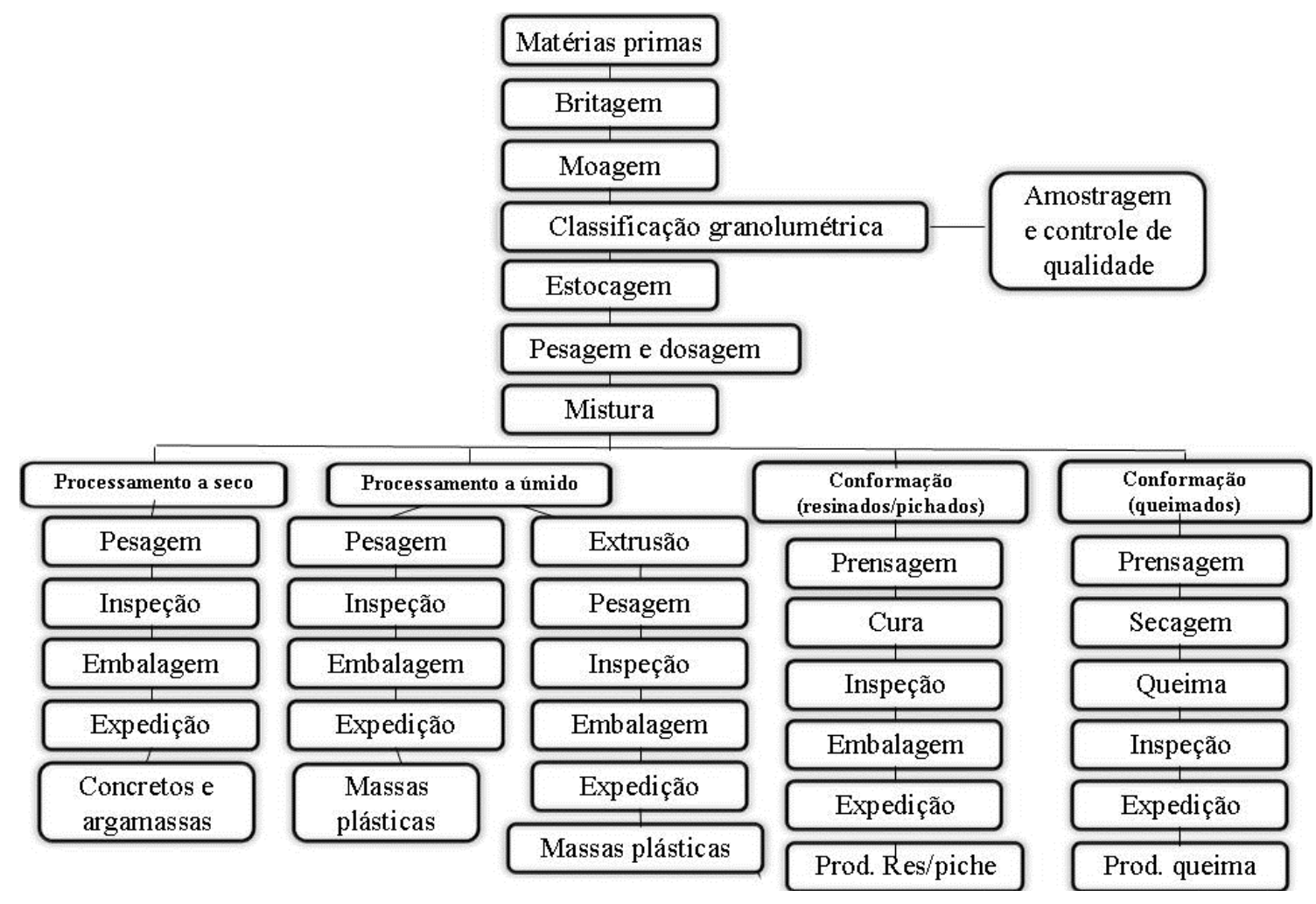

Figura 3- Produção de refratários

Fonte: SILVA adaptada, 2011, p.263.

A definição do projeto refratário é específica para cada usuário (usina, reator, ciclo operacional, carteira de produtos). Porém, de modo geral, pode-se dividir a aplicação dos refratários em algumas classes e tipos de produtos para as áreas de redução e aciaria (SILVA, 2011).

A redução engloba os altos-fornos, a área de corrida e de transporte de gusa líquido. Para os altos-fornos existe uma vasta gama de produtos: dos blocos de carbono utilizados nas regiões dos cadinhos aos tijolos sílico-aluminosos, aluminosos e de aluminacarbeto de silício-carbono. As propriedades e especificações técnicas dependem basicamente da posição de aplicação dos refratários ao longo do forno, do tipo de interação com as matérias-primas e dos produtos das reações de transformações metalúrgicas dentro do alto-forno, tais como: características das matérias-primas; interação sólido-sólido, sólido-gás e sólido-líquido; temperaturas e gradientes térmicos; qualidade do ferro gusa; volume de escória; ciclos operacionais de aberturas para vazamento do gusa/escória (SILVA, 2011).

Porém, o mesmo autor ressalta que a aciaria é onde se encontram as maiores variações de composição, formatos e tipos. É também o local de maior aplicação e consumo dos materiais refratários em uma usina siderúrgica, seja na forma de tijolos, concretos, argamassas, materiais de projeção, fibras isolantes ou dispositivos especiais.

Essa grande quantidade de tipos de refratários gera uma série de classificações. Dependendo do estado físico, os refratários são classificados quanto à forma em moldados e monolíticos, como citado anteriormente. Também podem ser classificados quanto à composição química em refratários básicos, não básicos e especiais; quanto ao tratamento térmico em queimados, eletrofundidos, quimicamente ligados 
e pré-moldados; e quanto ao poder de isolamento em densos e isolantes (DUARTE, 2012).

Assim, a seleção do refratário ideal para cada aplicação depende, entre outros fatores, da temperatura do processo, da agressividade química do meio e das ações físicas às quais está submetida (IBAR, 2012). Com isso, o desempenho dos materiais refratários depende de uma série de fatores, que vão desde a escolha adequada da especificação técnica do projeto de engenharia até as variações operacionais dos processos metalúrgicos (SILVA, 2011), definindo o padrão de desgaste do revestimento (MENEZES, 1989). Segundo Araújo (1997), o consumo do refratário dependerá então do tipo de revestimento, tipo de equipamento (região e geometria de onde será aplicado) e do programa de produção.

Os mecanismos de desgaste em refratários podem ser classificados genericamente como térmicos, mecânicos e químicos. Os primeiros são originados por tensões resultantes de taxas não uniformes de expansão ou contração, associadas às variações de temperaturas. Os mecânicos são causados por impacto ou pressão, tal como acontece pela ausência de coeficiente de dilatação em revestimentos (que gera trincas por tensões excessivas na face quente durante o aquecimento). E o último é causado por tensões geradas por alterações na microestrutura ao longo do refratário (DUARTE, 2003).

Dentro de cada uma destas classes, outros mecanismos devem ser considerados. Em geral, não há um único mecanismo atuando sobre o refratário, mas uma combinação entre eles. A correta identificação destes mecanismos é fundamental na busca de uma melhor performance do revestimento, com o consequente aumento da disponibilidade do equipamento (DUARTE, 2000).

\subsection{REFRATÁRIOS PARA DISTRIBUIDOR}

O distribuidor é um dos componentes que integram a máquina de lingotamento contínuo, Figura 4. Trata-se de um recipiente metálico revestido internamente por material refratário, para suportar temperaturas elevadas impostas pelo aço líquido. Pode possuir formas variadas, dependendo do projeto de cada fabricante. Tem como funções a flotação de inclusões (compostos não metálicos indesejáveis na estrutura cristalina do aço) e funcionar como reservatório intermediário, permitindo produzir uma série de corridas de forma ininterrupta (FACO, 2011).

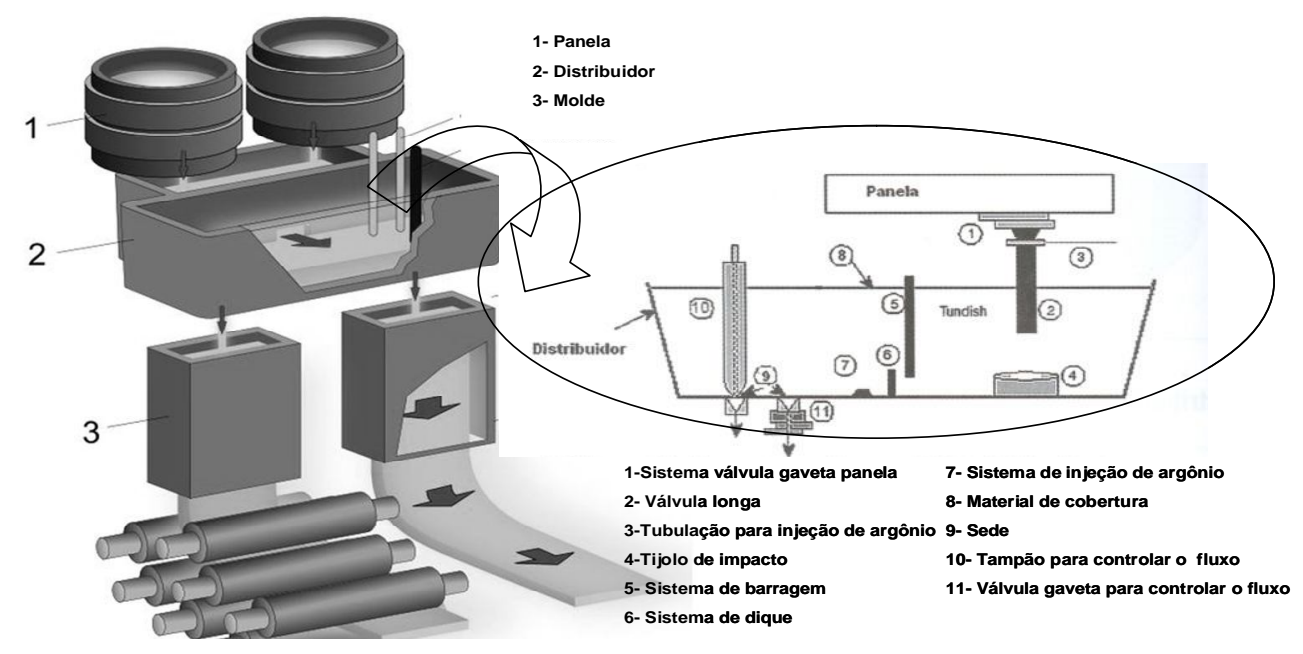

Figura 4- Lingotamento Contínuo/ Distribuidor Fonte: FACO modificada, 2011, p.226. 
O revestimento refratário de um distribuidor é composto por três camadas, como mostrado na Figura 5. Junto à carcaça do distribuidor aplica-se o revestimento isolante (que pode ser de tijolos ou monolítico) com objetivo de minimizar a perda de calor, isolando termicamente 0 interior desse equipamento do ambiente externo (GALLO, 2000).

Sobre essa camada isolante aplica-se o revestimento permanente visando proteger a carcaça contra eventuais vazamentos de aço que podem vir a ocorrer após desgaste total do revestimento de trabalho, ou por falhas durante sua utilização. Normalmente esse revestimento é de tijolos de alta alumina (GALLO, 2000).

O mesmo autor demonstra que, para proteger o revestimento permanente, aplica-se o revestimento de cobertura, que é usualmente composto por material básico $(\mathrm{MgO})$, e deve possuir elevada resistência à erosão para resistir ao lingotamento sequencial, sem provocar contaminação do aço.

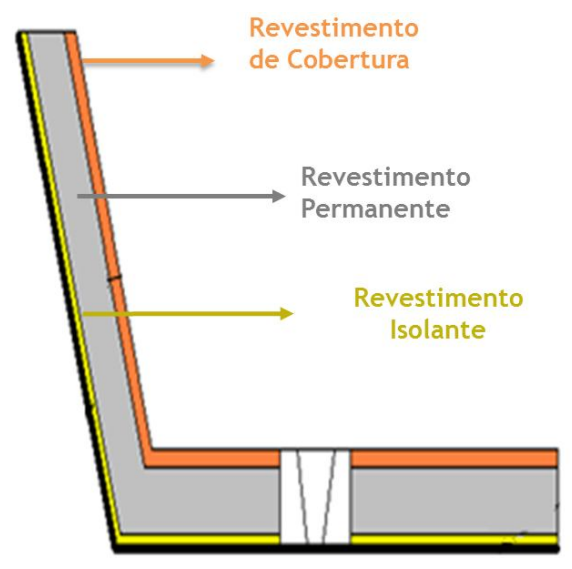

Figura 5 - Camadas revestimento distribuidor

\subsection{TESTES COM REFRATÁRIOS}

A compreensão dos produtos refratários e aplicação da tecnologia envolvem 0 conhecimento dos procedimentos de ensaio e as funções de tais testes. No entanto, esta análise de valor funcional dos testes de refratários é incompleta se dois fatores críticos forem omitidos: propriedades específicas físicas e químicas do produto; e as características da instalação (HANCOCK, 1988). Os testes com refratários são de extrema importância para desenvolvimento de novos produtos, otimização de produtos existentes, ou ainda análise de refratários usados.

Para isso realiza-se uma comparação com as propriedades específicas do produto em análise, e averigua-se se são suficientes para o local de instalação, de acordo com as características prédefinidas. Para cada estudo existem testes específicos necessários, seja pelo objetivo do estudo, pelo local de aplicação do refratário ou pela classe de refratário. São abordados, neste estudo, os testes mais frequentemente utilizados para se compreender os produtos refratários.

\subsubsection{DENSIDADE/ POROSIDADE}

Densidade é uma grandeza bastante importante, pois interfere diretamente em outras características, como a condutividade térmica, resistência mecânica etc. Nem sempre se pode medir diretamente o volume de uma peça, uma vez que as geometrias normalmente são complexas e os materiais refratários apresentam descontinuidades e imperfeições, como trincas e poros, que podem ser abertos ou fechados. Em virtude disto, podem definir diferentes tipos de cálculo de densidade, dentre eles os de densidade real e densidade aparente. $\mathrm{O}$ cálculo da densidade real é definido como sendo a massa por unidade de volume sem incluir os poros, enquanto o cálculo da densidade aparente é definido como sendo a massa do material dividido pelo volume, neste caso os poros fechados são incluídos, porém não são medidos (SILVA, 2011). A porosidade deve ser então obtida para o cálculo da densidade aparente, trata-se da razão entre o volume 
vazio de uma amostra para o seu volume total. Materiais refratários contêm poros abertos e fechados, e a porosidade aparente se refere aos poros abertos, enquanto que a porosidade, total ou verdadeira, inclui poros abertos e fechados (HANCOCK, 1988). De maneira geral, os refratários de baixa porosidade possuem melhor resistência ao ataque químico; à corrosão; à penetração de gases, escórias e metal líquido; e à erosão (SILVA, 2011).

\subsubsection{RESISTÊNCIA À ABRASÃO E À EROSÃO}

A resistência à abrasão e à erosão são propriedades importantes dos materiais refratários, especialmente quando eles são aplicados em zonas de fluxo de material particulado (abrasão) ou em contato com fluidos em movimento (erosão). Usualmente, os materiais com elevada resistência à abrasão apresentam elevados módulo de ruptura e resistência à compressão a frio (SILVA, 2011).

\subsubsection{RESISTÊNCIA MECÂNICA}

À medida da resistência à compressão à temperatura ambiente (RCTA) é, usualmente, um parâmetro de controle de qualidade que visa garantir a integridade física das peças; inferir sobre a homogeneidade dos tratamentos térmicos de produtos queimados; avaliar a atuação do sistema ligante (mistura e prensagem) de produtos resinados; de forma que a resistência mecânica dos materiais seja suficiente para uma etapa segura de manuseio e aplicação dos refratários, além de dar uma indicação indireta de outras propriedades como a própria abrasão (SILVA, 2011). Na prática, deseja-se uma faixa de RCTA para que se possam manusear as peças refratárias. A RCTA é importante no transporte dessas peças, já que, se for baixa, acarreta quebras durante 0 transporte. Os refratários que trabalham em contato com cargas erosivas, como é o caso dos usados em alto-forno, devem possuir elevada RCTA (GONÇALVES, 2009).

Já a resistência à flexão à temperatura ambiente (RFTA) ou módulo de ruptura à temperatura ambiente (MRTA) é um ensaio mais sensível e bastante útil para o desenvolvimento e especificações de aplicação dos refratários, sujeitos a carregamentos de esforços mais complexos (SILVA, 2011).

Em geral, segundo Gonçalves (2009), a RFTA ou MRTA é de 5 a 7 vezes menor do que a RCTA. Quando maior a RFTA significa que mais ceramizado está o refratário. Por outro lado, se a RFTA der abaixo da faixa de controle, provavelmente é devido à presença de micro trincas originadas durante a queima dos refratários, e é um problema que deve ser contornado.

\subsubsection{RESISTÊNCIA À CORROSÃO}

Os materiais refratários estão em contato com metais e escórias líquidas durante as etapas de transformação e refino metalúrgico. $O$ ataque químico ao refratário (corrosão) é uma das principais causas de afastamento para a manutenção dos reatores metalúrgicos. Uma das maneiras de se inferir sobre a resistência dos materiais refratários à corrosão é a realização de testes em escala laboratorial, que podem ser estáticos ou dinâmicos, com ou sem controle da atmosfera gasosa (SILVA, 2011).

O teste de escorificação estática é o teste mais simples de escorificação, no qual se realiza um furo em um pedaço do material refratário, onde é colocado um pouco de escória e metal; ou somente a escória. O conjunto é submetido a uma temperatura mais elevada que as condições operacionais do processo. O teste de escorificação rotativa é realizado em um forno cilíndrico de laboratório e é utilizado principalmente para a massa de tamponamento, massas e concretos. É um teste simples e permite 
comparar escórias diferentes. O teste de escorificação dinâmica é realizado no forno de indução e podem ser usados escória e metal. O resultado final do teste é a formação de uma região bem delineada desgastada pela escória (linha de escória), e outra pelo metal (linha de metal) (GONÇALVES, 2009).

\subsubsection{RESISTÊNCIA AO CHOQUE TÉRMICO}

As variações de temperatura podem causar severos danos aos revestimentos refratários, como micro e macrofissuramento (termoclasse térmica). A extensão do dano causado depende de uma série de fatores, tanto intrínsecos aos refratários (composição química, porosidade, resistência mecânica da matriz e agregados refratários, espessura do revestimento, dilatação diferencial dos componentes) quanto extrínsecos (ciclo térmico, encharcamento térmico do revestimento, tipo de aquecimento inicialmente realizado). A resistência ao choque térmico depende das interações entre os defeitos (nucleação de trincas) e de como estes defeitos evoluem ao longo do tempo (interação/propagação das trincas), como esclarece Silva (2011). O teste expressa a capacidade do material para suportar a tensão gerada pela variação rápida de temperatura (GONÇALVES, 2009).

\subsubsection{RefrataRiedade}

A refratariedade dos materiais refratários é determinada através do ensaio do cone pirométrico equivalente (PCE), em que se tem um ponto inicial de formação de líquido, uma mistura líquido mais sólido, e um ponto final de fusão (quando desaparecem completamente os sólidos) (SILVA, 2011). Este teste fornece uma ideia da temperatura de amolecimento do refratário ou matéria-prima (GONÇALVES, 2009).

\subsubsection{DilatAÇÃo térMICA REVERSíveL}

Todos os materiais refratários expandem quando aquecidos e contraem quando resfriados. Se não ocorrer uma mudança permanente nas dimensões originais, esse efeito é conhecido como expansão térmica reversível (HANCOCK, 1988). Isso ocorre porque quando os materiais refratários recebem energia (calor), as ligações entre os átomos se distanciam em decorrência do aumento das vibrações atômicas. A consequência deste processo reversível (quando não ocorrem transformações de fase) é o aumento das dimensões dos materiais (expansão) (SILVA, 2011). Pode-se então medir esta expansão, obtendo um valor para cada temperatura. Isto é extremamente útil para dimensionar as juntas de dilatação, levantando em conta a expansão ou contração irreversível e a dilatação térmica reversível (GONÇALVES, 2009).

\subsubsection{CONDUTIVIDADE TÉRMICA}

Outra propriedade muito importante dos materiais refratários é a condutividade térmica, uma vez que uma das principais funções dos refratários é a retenção de calor durante os processos metalúrgicos, de modo a minimizar as perdas de calor (energia) dos sistemas. A condutividade térmica é um parâmetro importante para a determinação dos estados de tensão, decorrentes de gradientes térmicos, para o projeto de composições refratárias de elevada resistência ao choque térmico (SILVA, 2011), é uma medida da habilidade de um material transmitir calor (HANCOCK, 1988).

Uma baixa condutividade térmica corresponde a uma baixa transmissão de calor (alto valor de isolamento), e a alta condutividade térmica, a uma alta transmissão (baixo valor de isolamento). O ar tem uma baixa condutividade térmica, assim isolantes refratários são altamente porosos. A elevada condutividade inerente 
do material sólido refratário é reduzida pela baixa condutividade do ar aprisionado nos poros (HANCOCK, 1988).

\subsubsection{FLUORESCÊNCIA DE RAIOS-X}

A presença de pequenas quantidades de impurezas é geralmente crítica nos produtos refratários, isso porque influenciam a quantidade e a temperatura de formação de líquido dentro do refratário. A análise química de um material, além de definir a quantidade dessas impurezas, também dá a quantidade dos óxidos refratários. Isso pode ser determinado pela técnica clássica de via úmida ou por técnicas instrumentais como fluerescência de raios- $x$ (FRX) (HANCOCK, 1988).

\subsubsection{DIFRAÇÃO DE RAIOS-X}

Comparações de produtos refratários baseados nas análises químicas não são suficientes, já que nenhuma indicação da forma dos óxidos presentes é dada. A técnica de difração de raios-x (DRX) é usada para mostrar a forma cristalina dos óxidos e constatar se eles estão presentes como óxidos simples ou compostos. Por isso, a técnica de DRX é largamente usada para determinar as fases presentes no refratário após operação e, consequentemente, determinar o mecanismo de falha nas condições de escorificação (HANCOCK, 1988).

\subsubsection{MICROESTRUTURA}

A técnica metalográfica de fixação de amostras e polimento, visando examiná-las sob um microscópio, usando luz refletida (microscopia ótica), pode também ser usada em materiais refratários. As fases presentes e o grau de ligação podem ser determinados, e essa técnica é frequentemente usada em conjunto com a DRX (HANCOCK, 1988). A microscopia ótica fornece informações interessantes, tais como a distribuição das fases mineralógicas majoritárias e minoritárias existentes na amostra. Permite também determinar o diâmetro médio dos cristais das matérias-primas e dos refratários acabados e usados (GONÇALVES, 2009).

As propriedades mais usadas na avaliação dos refratários são a capacidade do material de resistir às tensões causadas por expansão térmica, choque térmico e/ou cargas mecânicas (DUARTE, 2003). Na maioria das aplicações de refratários, as propriedades individuais do material que está sendo usado são de extrema importância. É raríssimo, entretanto, encontrar uma aplicação em que somente um mecanismo de desgaste esteja presente e em que apenas uma propriedade deva ser considerada. É sempre importante considerar todas as condições que possam afetar o revestimento refratário em uso. Os testes irão auxiliar exatamente na simulação dessas condições para que seja possível avaliar o uso do refratário no local de aplicação. Quando isto é feito, torna-se possível escolher um produto com a melhor combinação de propriedades que possa ter o desempenho esperado pelo usuário (DUARTE, 2000). Por isso, ao selecionar um material refratário, é necessário conhecer as propriedades físicas e químicas mais importantes, além das condições de serviço (MATOS, 2001).

\section{Metodologia}

Neste estudo foram avaliadas as causas de uma baixa campanha de um tijolo refratário usado em um distribuidor de uma usina siderúrgica. Para realização desse estudo de caso, foram coletados dois tijolos da região afetada, e ainda foi realizada uma análise da escória a qual interagiu com tais tijolos. Os testes realizados foram definidos com base na necessidade para se chegar à conclusão do que motivou a baixa campanha do tijolo. Também é importante buscar informações sobre o funcionamento do equipamento 
para complementar o estudo, associando com os resultados dos testes.

Esse tipo de estudo recebe o nome de análise PostMortem devido ao fato de analisar um material usado que não será mais submetido ao uso. Para realizar esse estudo, o levantamento de dados deve ser o mais completo possível, com informações do processo, análise da escória, registros fotográficos da região considerada. Tal estudo é realizado conforme as etapas apresentadas na Tabela 1, seguindo os passos nela apresentados.

Tabela 1

Estudo Post-Mortem

\begin{tabular}{|c|c|c|}
\hline ETAPA & TAREFA & VARIÁVEIS \\
\hline $\begin{array}{l}\text { Definição de } \\
\text { estudo post- } \\
\text { mortem }\end{array}$ & $\begin{array}{l}\text { Levantamento das } \\
\text { condições } \\
\text { operacionais às } \\
\text { quais o material } \\
\text { esteve sujeito. }\end{array}$ & $\begin{array}{l}\text { Tempo de operação; } \\
\text { Tratamentos metalúrgicos; } \\
\text { Carga média transportada; } \\
\text { Temperaturas; } \\
\text { Paradas operacionais; } \\
\text { Intervenções mecânicas; } \\
\text { Escórias. }\end{array}$ \\
\hline $\begin{array}{l}\text { Coleta } \quad \mathrm{da} \\
\text { amostra }\end{array}$ & $\begin{array}{l}\text { Coleta e } \\
\text { identificação do } \\
\text { correta da } \\
\text { posicionamento da } \\
\text { amostra. }\end{array}$ & $\begin{array}{l}\text { Dispositivo para coleta; } \\
\text { Tempo de espera. }\end{array}$ \\
\hline $\begin{array}{l}\text { Envio } \quad \mathrm{da} \\
\text { amostra }\end{array}$ & $\begin{array}{l}\text { Embalagem, } \\
\text { identificação } \\
\text { envio } \\
\text { amostras. }\end{array}$ & $\begin{array}{l}\text { Tempo; } \\
\text { Acondicionamento. }\end{array}$ \\
\hline $\begin{array}{l}\text { Recebimento } \\
\text { da amostra }\end{array}$ & $\begin{array}{l}\text { Análise inicial e } \\
\text { definição dos } \\
\text { testes a serem } \\
\text { realizados. }\end{array}$ & $\begin{array}{l}\text { Fotografias; } \\
\text { Observações iniciais; } \\
\text { Formato; } \\
\text { Trincas; } \\
\text { Cheiro; } \\
\text { Área reagida; } \\
\text { Metais ou escória. }\end{array}$ \\
\hline $\begin{array}{l}\text { Definição dos } \\
\text { testes }\end{array}$ & $\begin{array}{l}\text { Mecânicos, } \\
\text { químicos, físicos, } \\
\text { microscopia. }\end{array}$ & $\begin{array}{l}\text { Porosidade; } \\
\text { Densidade; } \\
\text { Composição química; } \\
\text { Seção polida. }\end{array}$ \\
\hline $\begin{array}{l}\text { Realização } \\
\text { das análises e } \\
\text { conclusões } \\
\text { sobre os } \\
\text { mecanismos } \\
\text { de desgaste, }\end{array}$ & $\begin{array}{l}\text { Análise, } \\
\text { modelamento e } \\
\text { diagnóstico da } \\
\text { falha. }\end{array}$ & Avaliação das melhorias. \\
\hline
\end{tabular}

Fonte - SILVA, 2011, p.297.

\subsection{ESTUDO DE CASO}

Como levantamento das condições operacionais obteve-se informações de que o distribuidor furou, provocando vazamento de aço, quando este se encontrava com 33 corridas lingotadas, sendo que normalmente operam com até 55 corridas. O furo ocorreu na primeira fiada, isto é, próximo ao fundo do distribuidor, na parede do bico, do lado direito, conforme Figura 6. Foi realizado, também, um levantamento da análise química da escória.

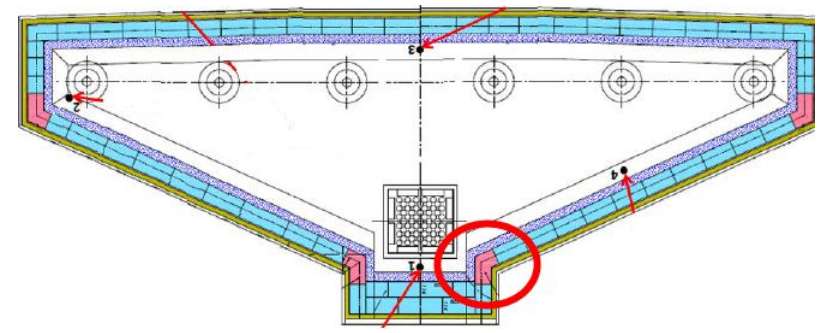

Figura 6 - Região Onde Ocorreu o furo do Distribuidor

De acordo com o registro fotográfico, os tijolos do revestimento permanente estavam com coloração escura no lado direito, enquanto no lado esquerdo o tijolo apresentava coloração escura somente na face quente. A Figura 7 é referente à foto dos tijolos permanentes da parede do bico, do lado esquerdo, mostrando a variação da coloração na face quente.

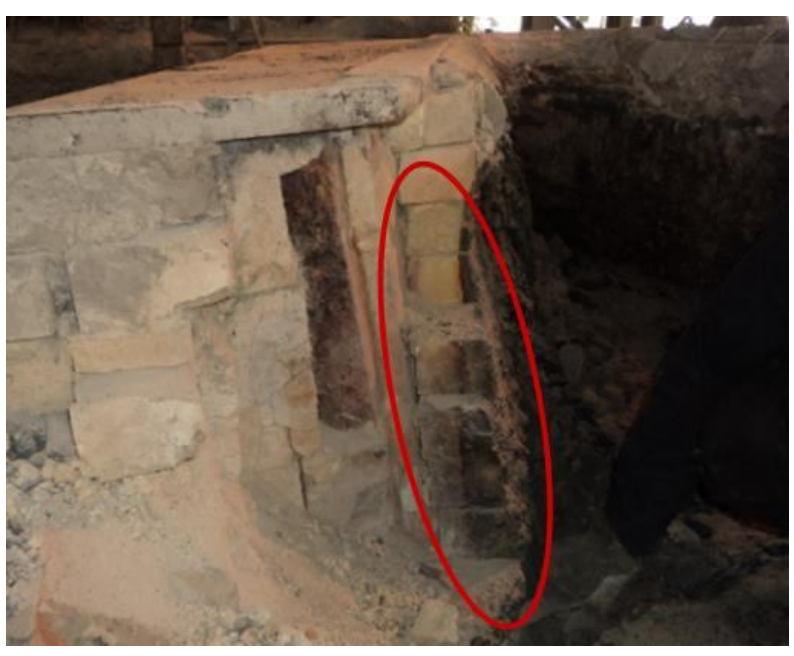

Figura 7 - Variação da coloração do tijolo permanente 
A segunda etapa do estudo corresponde à coleta e posicionamento das amostras. As amostras foram coletadas de acordo com a visualização da região afetada, sem a necessidade de realização de uma análise estatística. Foram retiradas amostras do tijolo totalmente escuro do lado direito do distribuidor (Amostra Escura) e do tijolo escuro somente na face quente, do lado esquerdo do distribuidor (Amostra Multicor). A Figura 8 mostra a região do distribuidor de onde foram coletadas as amostras. Posteriormente, na terceira etapa, essas foram devidamente identificadas, embaladas e enviadas para estudo.

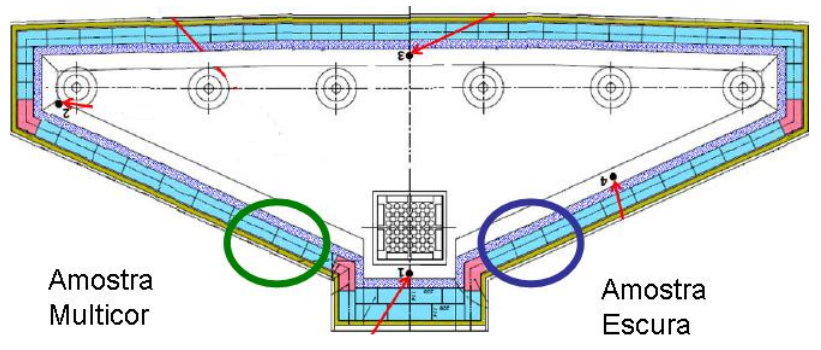

Figura 8 - Regiões de onde foram coletadas amostras para análise

Após o recebimento das amostras, elas foram divididas em quatro faces, identificadas conforme é mostrado nas figuras 9 e 10 .

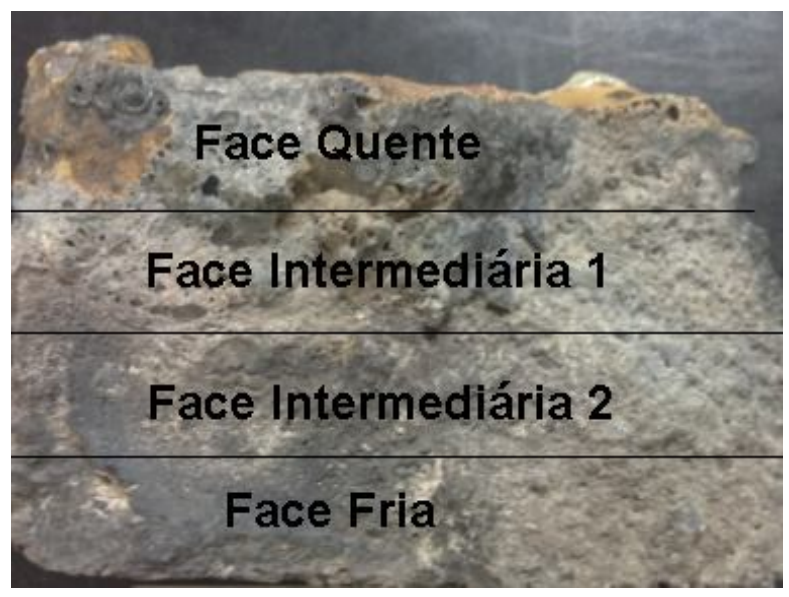

Figura 9 - Amostra Escura enviada para teste: Face Fria (FF/ 0 a 20mm), Face Intermediária 2 (Fl-2 /20 a $40 \mathrm{~mm})$, Face Intermediária 1 (FI-1/ 40 a 60mm) e Face Quente (FQ/ 60 a 75mm)

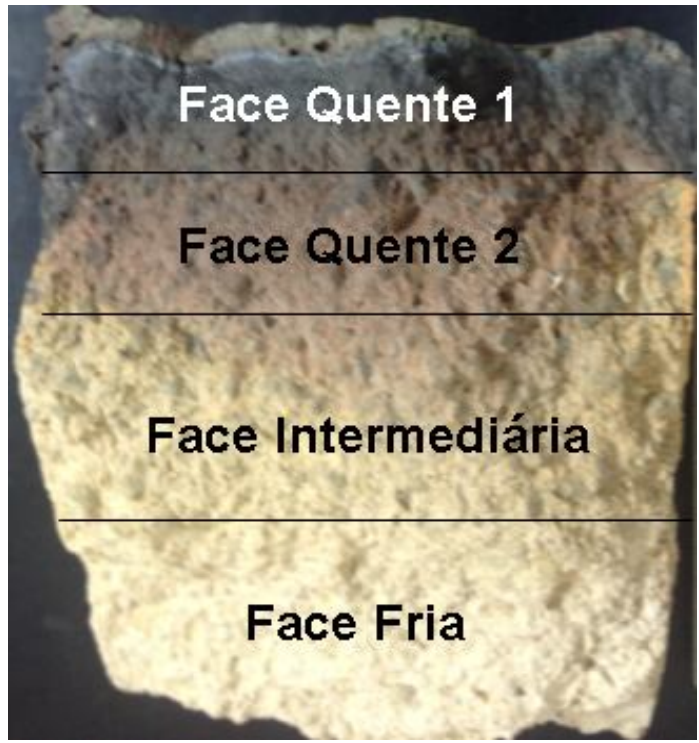

Figura 10- Amostra Escura enviada para teste: Face Fria (FF / 0 a $30 \mathrm{~mm}$ ), Face Intermediária (FI/ 30 a 60 $\mathrm{mm}$ ), Face Quente 2 (FQ-2/ 60 a $80 \mathrm{~mm}$ ) e Face Quente 1 (FQ-1/ 80 a $95 \mathrm{~mm}$ ).

Com cada uma das faces dos tijolos foram realizados testes de análise química por fluorescência de raios- $x$, difração de raios- $x$, perda ao fogo, densidade e porosidade, e microscopia nos laboratórios do Centro de Pesquisa e Desenvolvimento da Magnesita. $\mathrm{Na}$ etapa seguinte, foram executadas as análises e a avaliação dos mecanismos de desgaste, possibilitando diagnosticar a falha e avaliar possíveis melhorias.

\section{Resultados E discussão}

Foi feito um levantamento do histórico da análise química da escória do distribuidor. A Tabela 2 mostra a análise química média encontrada neste levantamento, bem como dados de relações $\mathrm{CaO} / \mathrm{SiO}_{2}, \mathrm{MgO}$ de saturação e temperatura de líquidus. calculados a partir dessa análise química, utilizando-se o software Termcalc. 
Tabela 2

Análise Química Escória do Distribuidor

\begin{tabular}{cc}
\cline { 2 - 2 } & Escória \\
\hline$\% \mathrm{CaO}$ & 19,53 \\
$\% \mathrm{SiO} 2$ & 28,93 \\
$\% \mathrm{MgO}$ & 11,80 \\
$\% \mathrm{FeO}$ & 4,84 \\
$\% \mathrm{MnO}$ & 30,42 \\
$\% \mathrm{Al} 2 \mathrm{O} 3$ & 0,37 \\
$\% \mathrm{P} 2 \mathrm{O} 5$ & 0,18 \\
$\% \mathrm{Cr} 2 \mathrm{O} 3$ & 0,12 \\
$\% \mathrm{SO} 2$ & 0,05 \\
$\% \mathrm{~F}$ & 1,41 \\
$\mathrm{CaO} / \mathrm{SiO} 2$ & 0,68 \\
$\mathrm{MgOSat}$ & 23,35 \\
Tliq & 1238,21 \\
\hline
\end{tabular}

Pela análise da escória, percebe-se que o teor necessário de $\mathrm{MgO}$ de saturação é muito maior que o teor de $\mathrm{MgO}$ presente, desta forma a escória precisa de mais $\mathrm{MgO}$ para se saturar. Normalmente, para se conseguir essa condição de saturação, são utilizados, como fonte de $\mathrm{MgO}$, condicionadores de escória. Porém, foi relatado pelo operador do lingotamento contínuo que o condicionador de escória utilizado estava vencido e não estava se diluindo na amostra Desta forma, a escória irá roubar $\mathrm{MgO}$ da massa refratária de trabalho, corroendo-a, causando desgaste excessivo.

A análise química também indica a presença de flúor $(1,41 \%)$ provavelmente na forma de fluorita, que normalmente é adicionada no distribuidor para capturar inclusões não metálicas do aço. A fluorita é responsável pelo abaixamento da temperatura de fusão da escória (T liq 1238,21 ํㅡ), fazendo com que a escória torne-se muito fluida e agressiva ao refratário, causando sua erosão. Além disso, tem-se uma relação $\mathrm{CaO} / \mathrm{SiO}_{2}$ menor do que um, indicando que a escória tem caráter ácido, que reage com a massa de cobertura básica. Por esses motivos, o revestimento de trabalho não suportou as condições de operação e o distribuidor passou a operar sob o revestimento permanente.

A Tabela 3 mostra os resultados obtidos para a amostra escura.

Tabela 3

Amostra Escura

\begin{tabular}{|c|c|c|c|c|c|}
\hline Faces & $F Q$ & $\mathrm{Fl}-1$ & $\mathrm{FI}-2$ & FF & $\begin{array}{l}\text { Tijolo } \\
\text { novo }\end{array}$ \\
\hline $\begin{array}{l}\text { D.M.A. } \\
\left(\mathrm{g} / \mathrm{cm}^{3}\right)\end{array}$ & 3,05 & 3,11 & 3,02 & 2,95 & 2,79 \\
\hline P.A( \%) & 2,57 & 2,95 & 7,0 & 8,1 & 17,6 \\
\hline DRX & $\begin{array}{l}\text { Coríndon } \\
\text { Mulita } \\
\text { Hercinita } \\
\text { Anortita } \\
\text { Rutilo } \\
\text { Ilmenita }\end{array}$ & $\begin{array}{c}\text { Coríndon } \\
\text { Mulita } \\
\text { Hercinita } \\
\text { Ilmenita } \\
\text { Anortita } \\
\text { Rutilo }\end{array}$ & $\begin{array}{l}\text { Coríndon } \\
\text { Mulita } \\
\text { Ilmenita } \\
\text { Rutilo }\end{array}$ & $\begin{array}{l}\text { Coríndon } \\
\text { Mulita } \\
\text { Ilmenita } \\
\text { Rutilo }\end{array}$ & \\
\hline \multicolumn{6}{|l|}{$\begin{array}{c}\text { Análise } \\
\text { química } \\
(\%)\end{array}$} \\
\hline P.F. & $-0,13$ & $-0,11$ & $-0,11$ & $-0,10$ & \\
\hline $\mathrm{SiO}_{2}$ & 19,34 & 18,05 & 15,31 & 15,92 & 14,30 \\
\hline $\mathrm{TiO}_{2}$ & 3,00 & 2,95 & 2,99 & 3,01 & 3,30 \\
\hline $\mathrm{Al}_{2} \mathrm{O}_{3}$ & 71,66 & 73,54 & 79,19 & 78,58 & 80,00 \\
\hline $\mathrm{Cr}_{2} \mathrm{O}_{3}$ & 0,02 & 0,03 & 0,03 & 0,02 & \\
\hline $\mathrm{Fe}_{2} \mathrm{O}_{3}$ & 1,61 & 1,68 & 1,43 & 1,46 & 1,60 \\
\hline MnO & 0,83 & 0,55 & 0,01 & 0,07 & \\
\hline $\mathrm{CaO}$ & 1,56 & 1,14 & 0,10 & 0,22 & \\
\hline MgO & 1,30 & 1,47 & 0,19 & 0,18 & \\
\hline $\mathrm{Na}_{2} \mathrm{O}$ & 0,40 & 0,36 & 0,39 & 0,35 & 0,25 \\
\hline $\mathrm{K}_{2} \mathrm{O}$ & 0,10 & 0,08 & 0,05 & 0,06 & 0,25 \\
\hline $\mathrm{P}_{2} \mathrm{O}_{5}$ & 0,05 & 0,04 & 0,04 & 0,04 & \\
\hline $\mathrm{ZrO}_{2}$ & 0,13 & 0,09 & 0,09 & 0,09 & \\
\hline $\mathrm{SO}_{3}$ & 0,01 & 0,02 & 0,00 & 0,01 & \\
\hline Cloro & 0,00 & 0,00 & 0,00 & 0,00 & \\
\hline Flúor & 0,00 & 0,00 & 0,19 & 0,00 & \\
\hline
\end{tabular}

(FQ: face quente; FI-1: face intermediária 1; FI-2: face intermediária 2; FF: face fria).

Comparando com os dados do tijolo refratário novo, pode-se notar, a partir da análise química, a incorporação de óxidos como $\mathrm{MnO}, \mathrm{CaO}, \mathrm{MgO}$ e $\mathrm{SiO}_{2}$ ao tijolo, provavelmente vindos da escória. Essa incorporação de óxidos gerou a formação de fase líquida e, consequentemente, densificação do tijolo, principalmente nas Faces Quente e Intermediária, como pode ser visto na Tabela 3. E ainda a perda ao fogo negativa denota infiltração de Ferro Metálico, devido a sua oxidação. 
Em relação ao DRX, houve formação de fases inexistentes no tijolo original, como, por exemplo, Hercinita $\left(\mathrm{FeO} . \mathrm{Al}_{2} \mathrm{O}_{3}\right)$, Anortita $\left(\mathrm{CaO} . \mathrm{Al}_{2} \mathrm{O}_{3} .2 \mathrm{SiO}_{2}\right)$ e Ilmenita $\left(\mathrm{FeO} . \mathrm{TiO}_{2}\right)$, que contribuem para alteração de coloração do tijolo. Como houve infiltração estatisticamente semelhante em todas as faces do tijolo, este escureceu como um todo. A fase Anortita é formada quando o $\mathrm{CaO}$, proveniente da escória, rouba Sílica do Grão de Chamote, liberando cristais de Coríndon. A Tabela 4 mostra os resultados da amostra multicolor.

Tabela 4

Amostra Multicor

\begin{tabular}{|c|c|c|c|c|c|}
\hline Faces & $F Q-1$ & FQ-2 & FI & $\mathrm{FF}$ & $\begin{array}{l}\text { Tijolo } \\
\text { novo }\end{array}$ \\
\hline $\begin{array}{l}\text { D.M.A. } \\
\left(\mathrm{g} / \mathrm{cm}^{3}\right)\end{array}$ & 3,02 & 2,75 & 2,75 & 2,76 & 2,79 \\
\hline P.A (\%) & 4,97 & 16,43 & 17,1 & 16,9 & 17,6 \\
\hline DRX & $\begin{array}{c}\text { Coríndon } \\
\text { Mulita } \\
\text { Anortita } \\
\text { Espinélio } \\
\text { Nefelina }\end{array}$ & $\begin{array}{c}\text { Coríndon } \\
\text { Mulita } \\
\text { Tielita } \\
\text { Rutilo }\end{array}$ & $\begin{array}{c}\text { Coríndon } \\
\text { Mulita } \\
\text { Rutilo } \\
\text { Cristobali } \\
\text {-ta } \\
\text { Tielita }\end{array}$ & $\begin{array}{c}\text { Coríndon } \\
\text { Mulita } \\
\text { Tielita } \\
\text { Cristobali } \\
\text {-ta } \\
\text { Rutilo }\end{array}$ & \\
\hline \multicolumn{6}{|l|}{$\begin{array}{c}\text { Análise } \\
\text { química } \\
(\%)\end{array}$} \\
\hline P.F. & $-0,16$ & 0,02 & 0,04 & 0,05 & \\
\hline $\mathrm{SiO2}$ & 18,25 & 16,05 & 15,49 & 15,98 & 14,30 \\
\hline TiO2 & 3,07 & 3,13 & 3,14 & 3,14 & 3,30 \\
\hline $\mathrm{Al} 2 \mathrm{O} 3$ & 69,90 & 78,05 & 78,64 & 78,01 & 80,00 \\
\hline $\mathrm{Cr} 2 \mathrm{O} 3$ & 0,03 & 0,03 & 0,02 & 0,02 & \\
\hline $\mathrm{Fe} 2 \mathrm{O} 3$ & 2,12 & 1,65 & 1,61 & 1,61 & 1,60 \\
\hline MnO & 1,27 & 0,04 & 0,01 & 0,01 & \\
\hline $\mathrm{CaO}$ & 2,48 & 0,23 & 0,16 & 0,20 & \\
\hline $\mathrm{MgO}$ & 2,04 & 0,16 & 0,09 & 0,11 & \\
\hline $\mathrm{Na2O}$ & 0,44 & 0,45 & 0,42 & 0,51 & 0,25 \\
\hline K2O & 0,24 & 0,08 & 0,07 & 0,08 & 0,25 \\
\hline P2O5 & 0,05 & 0,05 & 0,06 & 0,04 & \\
\hline ZrO2 & 0,11 & 0,09 & 0,09 & 0,08 & \\
\hline $\mathrm{SO3}$ & 0,01 & 0,01 & 0,00 & 0,00 & \\
\hline Cloro & 0,00 & 0,00 & 0,00 & 0,00 & \\
\hline Flúor & 0,00 & 0,00 & 0,20 & 0,23 & \\
\hline
\end{tabular}

(FQ-1: face quente 1; FQ-2 face quente 2; Fl: face intermediária; FF: face fria).

Da mesma forma que ocorreu com a amostra escura, houve a incorporação de óxidos como $\mathrm{MnO}, \mathrm{CaO}$, $\mathrm{MgO}$ e $\mathrm{SiO}_{2}$ ao tijolo, provavelmente vindos da escória, somente na Face Quente 1. Essa incorporação de óxidos gerou a formação de fase líquida e, consequentemente, densificação dessa face, conforme a Tabela 4.

Em relação ao DRX, houve formação de fases inexistentes no tijolo original como, por exemplo, Anortita $\left(\mathrm{CaO} . \mathrm{Al}_{2} \mathrm{O}_{3} .2 \mathrm{SiO}_{2}\right)$ e Espinélio $\left(\mathrm{MgO} . \mathrm{Al}_{2} \mathrm{O}_{3}\right)$, responsáveis pela mudança de coloração do tijolo. Como a infiltração ocorreu somente na face quente, só houve mudança de coloração nessa região. Nota-se que não houve formação de Hercinita $\left(\mathrm{FeO} \cdot \mathrm{Al}_{2} \mathrm{O}_{3}\right)$ e IImenita $\left(\mathrm{FeO} \cdot \mathrm{TiO}_{2}\right)$, portanto pode-se concluir que nessa região não houve infiltração de aço significativa.

Ao comparar as fotos da microscopia óptica dos tijolos em análise (Figura 11) com de um tijolo sem utilização (Figura 12), pode-se perceber que os grãos de Chamote dos tijolos analisados encontram-se totalmente destruídos pela infiltração de aço e escória, o que se vê são Cristais de Coríndon rodeados por uma massa fundida, que é a Anortita. Fenômeno que comprova o processo de erosão causado pela escória sob a superfície de trabalho.

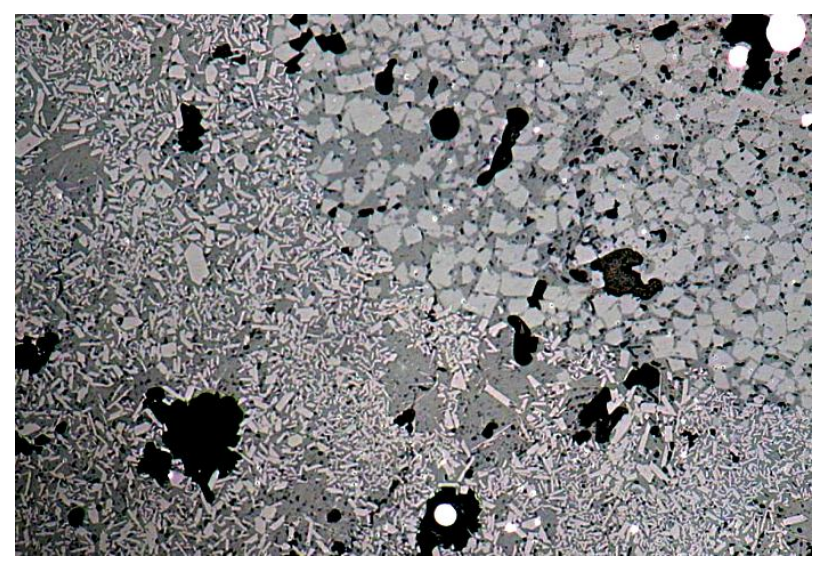

Figura 11 -Foto da Microscopia da Amostra Escura Zoom 100x - Detalhe para os pontos brancos, que correspondem à infiltração de aço . 


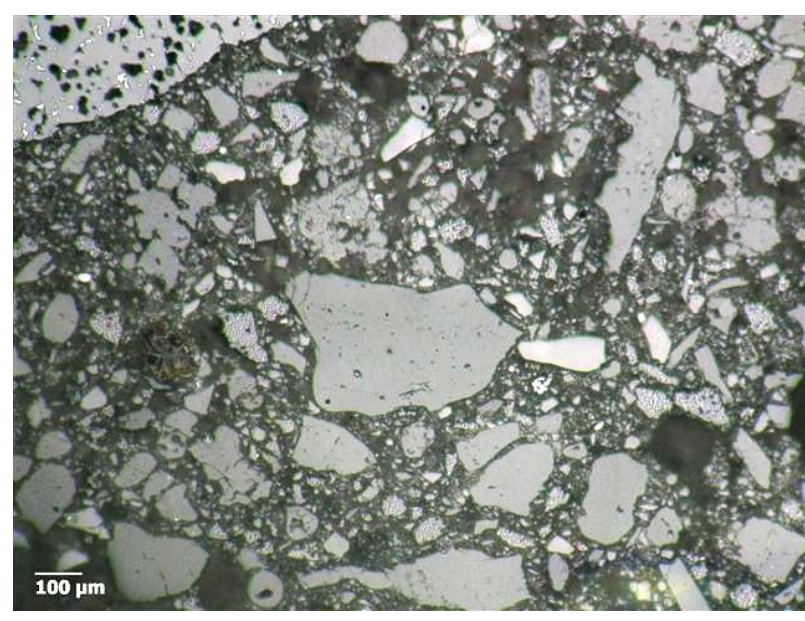

Figura 12-Foto da Microscopia de um tijolo sem utilização - Zoom 100x - Detalhe para os grãos intactos.

\section{ConcLuSÃo}

É sempre importante analisar os fatores que afetam a performance do revestimento refratário, que podem ser: operacionais; de projeto e montagem; e específicos das propriedades dos materiais usados. Excluindo os fatores operacionais, podem-se analisar então os tipos de mecanismos de desgaste que possam estar ocorrendo com o material refratário.

Visto que o desempenho dos materiais refratários depende de uma série de fatores que vão desde a escolha adequada da especificação técnica do projeto de engenharia até as variações operacionais dos processos metalúrgicos, uma das ferramentas mais úteis para a determinação das causas fundamentais das falhas dos revestimentos e entendimento dos mecanismos de desgaste é a realização de caracterizações sistemáticas do produto refratário após o término de sua campanha. Este tipo de estudo recebe o nome de análise Post-Mortem.

Porém, nem sempre é possível determinar a causa fundamental de um desgaste prematuro de um refratário através desse estudo. Uma vez que todas as mudanças que ocorreram durante a campanha não são detectáveis pelo estudo de Post-Mortem, mas somente aquelas modificações estruturais, químicas e mecânicas que aconteceram no final da vida do revestimento ou que permaneceram no material refratário.

A análise após o uso das propriedades dos materiais refratários é útil, tanto no aprimoramento dos produtos como também na melhoria das condições operacionais. A comparação das propriedades dos materiais após utilização com as suas propriedades originais ajuda a identificar o mecanismo de desgaste e as condições operacionais a que o refratário foi submetido. Para isso, é sempre importante analisar todas as condições operacionais e coletar amostras tanto do refratário usado quanto dos materiais que trabalharam em contato com ele.

Dentro desta análise, é importante considerar a interação entre os mecanismos e quais são os mais relevantes. Como os equipamentos são usados por um longo período, o tempo de utilização (número de corridas) torna-se um fator muito importante.

Visando entender as causas da baixa campanha e do furo ocasionado no distribuidor, realizou-se esse estudo de caso por análise Post-Mortem. A partir da análise química dos tijolos, verificou-se a incorporação de óxidos provavelmente vindos da escória, ocasionando a sua densificação, o que pode ser comprovado através dos ensaios de densidade e porosidade. A difração de raios-x mostrou a formação de fases inexistentes no tijolo original, que contribuem para a alteração da sua coloração.

Pela análise da escória que estava em contato com o tijolo, percebeu-se de que se tratava de uma escória de caráter ácido; com $\mathrm{MgO}$ de saturação muito maior que o teor de $\mathrm{MgO}$ livre presente na escória. Além disso, a temperatura de líquidus da escória estava baixa, indicando uma escória muito fluida e ainda mais agressiva ao refratário. Por esses motivos, a massa de cobertura do distribuidor, utilizada como revestimento de trabalho, não suportou as condições de operação e o distribuidor passou a operar sob o 
revestimento permanente, que não foi desenvolvido para trabalhar diretamente em contato com o metal líquido.

O projeto conta com uma massa de cobertura, desenvolvida para atuar em contato com o aço e a escória, que sinteriza em camadas, protegendo o revestimento permanente e evitando que este entre em contato com temperaturas elevadas durante um longo período de tempo. Ao contrário do revestimento de trabalho, a sinterização do revestimento permanente não ocorre em camadas, pois se trata de um produto com maior condutividade térmica. Devido a essa característica, a exposição a altas temperaturas por um tempo prolongado causa uma sinterização rápida e em toda a extensão do revestimento, podendo danificar a carcaça.

Assim, devido aos processos de reações químicas, erosão e corrosão entre a escória e o revestimento de cobertura, o revestimento permanente passou a atuar diretamente em contato com o aço, sinterizando por completo e permitindo que essa temperatura chegasse à carcaça, ocasionando o furo do distribuidor.

Constataram-se problemas de operações durante 0 processo, que deveriam ser adequados para que essa situação não se repetisse. Assim, sugere-se um controle eficaz da escória do distribuidor, se necessário, com adições de condicionadores de escória.

\section{AGRADECIMENTOS}

As autoras agradecem ao Centro de Pesquisa e Desenvolvimento da Magnesita pela oportunidade para realizar este estudo. À Adriana Mendes Correa, pelos ensinamentos, paciência, acompanhamento e enriquecimento ao trabalho. A todos aqueles que contribuíram de alguma forma com a elaboração do trabalho, com ensinamentos, aprendizagem ou auxílios nas execuções dos ensaios.

\section{REFERÊNCIAS}

ARAÚJO, L. Manual de siderurgia. 1 a Edição. São Paulo: editora arte \& ciência, 1997.v.1. 470 p. ISBN 85-86127-11-6.

BOLOTA, J. Refino secundário de aços. In: MOURÃO, Marcelo; et al. Introdução à siderurgia. Edição 2007. São Paulo: Associação Brasileira de Metalurgia, Materiais e Mineração (ABM), 2011. Capítulo 7. 189215. ISBN 978-85-7737-015-3.

DUARTE, A. Classificação de refratários. In: CURSO FUNDAMENTOS DE REFRATÁRIOS, 2012, Belo Horizonte. Classificação de refratários. 2012. Belo Horizonte: 2012.

DUARTE, A. Definição de refratários. In: CURSO FUNDAMENTOS DE REFRATÁRIOS, 2012, Belo Horizonte. Definição de refratários. 2012. Belo Horizonte: 2012.

DUARTE, A. Mecanismos gerais de desgastes em refratários. In: CURSO DE REFRATÁRIOS PARA ACIÁRIA ELÉTRICA, 2000, Belo Horizonte.

Mecanismos gerais de desgastes em refratários. 2000. Belo Horizonte: 2000. 77 - 95.
DUARTE, A. Propriedades dos materiais refratários. In: CURSO DE REFRATÁRIOS, 2003, Contagem. Propriedades dos materiais refratários. 2003. Belo Horizonte: 2003.

FACO, R. Lingotamento contínuo do aço. In: MOURÃO, M.; et al. Introdução à siderurgia. Edição 2007. São Paulo: Associação Brasileira de Metalurgia, Materiais e Mineração (ABM), 2011. Capítulo 8. 217255. ISBN 978-85-7737-015-3.

GALLO, M. Refratários para lingotamento contínuo. 1 a Edição. Belo Horizonte: Gráfica Lisboa, 2000.

GONÇALVES, G. A interpretação prática dos testes de qualidade executados pelo GCQ. In: PALESTRA GCQ, 2009, Belo Horizonte. A interpretação prática dos testes de qualidade executados pelo GCQ. 2009. Belo Horizonte, 2009.

HANCOCK, J D. Practical refractories. Huddersfield: Cartworth Industries, 1988. 371p. 
IBAR - INDÚSTRIA BRASILEIRA DE ARTIGOS REFRATÁRIOS, 2012. Disponível em: < http://www.ibar.com.br/quem-somos/refratarios.html> Acesso em: 19 nov. 2012.

LEANDRO, C. Fabricação de aço em fornos elétricos a arco. In: MOURÃO, M.; et al. Introdução à siderurgia. Edição 2007.São Paulo: Associação Brasileira de Metalurgia, Materiais e Mineração (ABM), 2011. Capítulo 6. 169-187. ISBN 978-85-7737-015-3.

MALYNOWSKYI, A. Fabricação de aço líquido em conversor a oxigênio. In: MOURÃO, M.; et al. Introdução à siderurgia. Edição 2007. São Paulo: Associação Brasileira de Metalurgia, Materiais e Mineração (ABM), 2011. Capítulo 5. 125-167. ISBN 978-85-7737-015-3.

MATOS, J. Concepção Cerâmica dos Produtos Básicos e Aplicações e Variáveis que Afetam no Desempenho. In: CONCEPÇÃO CERÂMICA DOS PRODUTOS FABRICADOS NA FÁBRICA DE BÁSICOS, 2001, Contagem. Concepção Cerâmica dos Produtos Básicos e Aplicações e Variáveis que Afetam no Desempenho. 2001. Contagem, 2001. 1-80.

MENEZES, I. Refratários: propriedades mecânicas, fratura e efeitos termomecânicos. In: SEMINÁRIO SOBRE ACIARIA E REFRATÁRIOS, 1989, VITÓRIA. Refratários: propriedades mecânicas, fratura $e$ efeitos termomecânicos. 1989. Belo Horizonte: 1989. 1-181.
MOREIRA, M. Siderurgia. Disponível em < http://www.dalmolim.com.br/EDUCACAO/MATERIAIS/ Biblimat/siderurgia2.pdf> Acesso em: 1 abr. 2013.

MOURÃO, M. Redução de minérios de ferro por redução direta e processos alternativos. In: MOURÃO, M.; et al. Introdução à siderurgia. Edição 2007.São Paulo: Associação Brasileira de Metalurgia, Materiais e Mineração (ABM), 2011. Capítulo № 4. 103-124. ISBN 978-85-7737-015-3.

MOURÃO, M. et al. Siderurgia para não siderurgistas. $2^{\mathrm{a}}$ ed. São Paulo.: Associação Brasileira de Metalurgia, Materiais e Mineração (ABM), 2002. $310 \mathrm{p}$.

MOURÃO, M.; GENTILE, E. Visão geral do processo siderúrgico. In: MOURÃO, M.; et al. Introdução à siderurgia. Edição 2007. São Paulo: Associação Brasileira de Metalurgia, Materiais e Mineração (ABM), 2011. Capítulo 1. 1-20. ISBN 978-85-7737-015-3.

QUITES, E. Redução de minérios de ferro em altosfornos. In: MOURẨO, M.; et al. Introdução à siderurgia. Edição 2007. São Paulo: Associação Brasileira de Metalurgia, Materiais e Mineração (ABM), 2011. Capítulo 3. 55-102. ISBN 978-85-7737-015-3.

SILVA, G. Refratários para siderurgia. In: MOURÃO, M.; et al. Introdução à siderurgia. Edição 2007. São Paulo: Associação Brasileira de Metalurgia, Materiais e Mineração (ABM), 2011. Capítulo no 9. 257-307. ISBN 978-85-7737-015-3. 